\title{
Текущее состояние и актуальные направления развития космической фотоэнергетики
}

\author{
С.Г. Кочура, С.И. Опенько, М.В. Нестеришин, П.А. Крючков, Е.О. Воронцова \\ Акционерное общество «Информационные спутниковые системы» \\ имени академика М.Ф. Решетнёва» \\ 662972, г. Железногорск Красноярского края, ул. Ленина, 52 \\ Телефон: +7 (3919) 72-24-39 Факс: +7 (3919) 75-61-46 E-mail: office@iss-reshetnev.ru
}

DOI 10.34077/RCSP2019-65

Наиболее распространённым и востребованным первичным источником энергии для космических аппаратов (КА) является солнечная батарея (БС). На сегодняшний день на орбите Земли функционирует $\approx 1800$ КА различного назначения, суммарная мощность БС которых составляет $\approx 15$ МВт, а масса $\approx 160$ тонн. [1]

Важнейшими требованиями при проектировании БС являются: повышение начальной энергоэффективности (КПД, удельная мощность по площади Вт/м2), обеспечение стойкости к фактором космического пространства, минимизация массы (кг/м2), минимизация объёма конструкции БС в сложенном состоянии при выведении на орбиту, минимизация стоимости.

Следуя выполнению таких требований и, главным образом, благодаря выравниванию стоимости фотопреобразователей (ФП) на основе арсенид-галлия (GaAs) по сравнению с ФП на основе кремния $(\mathrm{Si})$, в течение последний 10 лет в коммерческих и федеральных проектах произошёл массовый переход с $\mathrm{Si}$ ФП на GaAs ФП, благодаря чему удельная мощность по массе увеличилась с 75 Вт/кг до 190 Вт/кг, по площади с 130 Вт/м2 до 280 Вт/м2.

Очевидно, что в будущем потребуется расширить спектр задач, выполняемых космическими группировками. Одним из факторов выполнения таких требований является разработка и применение нового поколения ФП с КПД 38-39\% при меньшей массе. На сегодня имеются лабораторные образцы таких элементов. Дорожные карты развития в Мире показывают, что ФП с указанными характеристиками будут доступны к использованию уже в 2025 году. [2]

Разработка ФП является очень сложным научно-инженерным и технологически ёмким процессом. В отечественной фотоэнергетике начиная с 2000-х годов пройдён путь от использования покупных импортных фотопреобразователей при минимальной доле собственных работ в цикле производства БС, до производства с использованием отечественных германиевых подложек и самостоятельного выращивания ФП на импортном оборудовании.

Но процесс изготовление отечественных космических ФП начат «с конца». Производство проходит по воспроизведению имеющейся структуры, а не по самостоятельно разработанной. Таким образом мы подошли к той стадии, где необходимы более глубокие академические знания и помощь фундаментальной науки.

Учитывая вышесказанное, для отечественной космической фотоэнергетики наиболее актуальными задачами являются: разработка структуры перспективного ФП, технологии производства, создание опытно-промышленной линии производительностью $\approx 400$ м2/год и внедрение её на промышленные предприятия. Немаловажным является создание научной технологической школы по разработке перспективных ФП для космического применения в обеспечении постоянного совершенствования характеристик.

На данном этапе возлагаются большие надежды на плодотворное сотрудничество между производством и российской академической наукой с целью выполнения поставленных задач, повышения конкурентоспособности и качества продукции космического назначения.

\section{Лuтература}

[1] Журнал «Все о космосе» [Электронный ресурc]. URL: https://aboutspacejornal.net/2018/08/19/ union-of-concerned-scientists(дата обращения: 05.3.2019).

[2] Обзор современных фотоэлектрических преобразователей Космического назначения на основе соединений AIIIBV / Слыщенко Е. В. и др. // Сибирский журнал науки и технологий. 2018. Т. 19, № 2. C. $308-324$. 